\title{
Ostracode-based aminostratigraphy and aminochronology of a tufa system in central Spain
}

\author{
T. Torres ${ }^{\mathrm{a}, *}$, J.E. Ortiz ${ }^{\mathrm{a}}$, M.A. García de la Morena ${ }^{\mathrm{a}}$, F.J. Llamas ${ }^{\mathrm{a}}$, G. Goodfriend ${ }^{\mathrm{b}, \boldsymbol{w}}$ \\ ${ }^{a}$ Biomolecular Stratigraphy Laboratory, Madrid School of Mines, C/Ríos Rosas 21, E-28003 Madrid, Spain \\ ${ }^{\mathrm{b}}$ Department of Earth and Environmental Sciences, George Washington University, USA
}

\begin{abstract}
In the Priego area, central Spain, extensive tufa deposits are located in three small tributaries located at the head of the $1000 \mathrm{~km}$ long Tagus River. The deposits are originated after karst-origin running waters emerged from the confines of the canyons and expanded outward. Old tufa deposits of Priego are mainly present as terraced alluvial plain deposits where different autochthonous and allochthonous facies appear. Extraclastic deposits of quartzite and limestone clasts derived from Mesozoic rocks are interbedded with the tufa marking pulsatory high-flow periods. Using the geomorphologic analysis six terraced levels were differentiated and sampled for ostracode amino acid racemization analysis. $D / L$ ratios of aspartic acid and glutamic acid were used for dating purposes. Cluster analysis defined six aminozones (AM1-AM7) which were dated as follows: AM1: 407 $\pm 12 \mathrm{ka}$ oxygen isotope stages (OIS 11); AM2: $263 \pm 14 \mathrm{ka}$ (OIS 7e); AM3: $181 \pm 17 \mathrm{ka}$ (OIS 7a); AM4: $136 \pm 13 \mathrm{ka}$ (OIS 5-6); AM5: 108 $\pm 14 \mathrm{ka}$ (OIS 5); AM7: $11 \pm 4 \mathrm{ka}$ (OIS 1), indicating that tufa deposition took place during warm periods. Models of riverine and riverinebarrage tufa accumulation indicate that their maximum build-up took place between the canyon mouth and the point of depletion of dissolved $\mathrm{CO}_{2}$, and this affected the elevation of the top of the deposits and their relative chronology.
\end{abstract}

\section{Introduction}

According to Pedley (1990), the term tufa, more precisely "cool water tufa", is the most adequate to describe low-temperature cool (non-hydrothermal) freshwater highly porous carbonate deposits. Pre-existing organisms, usually plants, are preserved as moulds or casts. Tufa deposits have rarely been recognized in the pre-Pleistocene geological record. Evans (1999) described Eocene travertines and tufas in the Badlands of South Dakota. Leslie et al. (1992) found travertines from the Upper Triassic in Wales, UK. Torres and Zapata (1986) identified tufa deposits from the Lower Miocene in the Depresión Intermedia Basin (Spain), and Arenas et al. (2000) described tufa deposits from the Pre-Pleistocene in the Ebro Basin (NE Spain). In contrast, Pleistocene and Holocene groundwater-fed chemical deposits are distributed worldwide (Julià, 1980; Kempe and Emeis, 1985; Pedley, 1990; Pentecost, 1995; Ford and Pedley, 1996; Evans, 1999).

The ground-water feeding system (usually a karsted rock massif) controls the accumulation and preservation of tufa deposits. The hydrological and hydro-chemical karst-linked conditions control both chemical and biological degassing processes whilst $\mathrm{P}_{\mathrm{CO} 2}$ variations account for calcium carbonate precipitation (Jacobson and Usdowski, 1975; Julià, 1983; Emeis et al., 1987; Pentecost, 1992).

Underground (karstic) waters are calcium bicarbonate saturated and usually have an elevated $\mathrm{CO}_{2}$ partial pressure $\left(\mathrm{P}_{\mathrm{CO} 2}\right)$, which makes for stable calcium bicarbonate in dissolution. Any $\mathrm{P}_{\mathrm{CO} 2}$-lowering factor will be responsible for calcium carbonate $\left(\mathrm{CaCO}_{3}\right)$ deposition. Degassing is favoured by a sudden growth of the water-air interface and turbulence (Stumm and Morgan, 1981). 
The physico-chemical factors controlling the formation of tufa can be summarized as follows: tufa deposition was related to slow water motion and shallow water sheetflow in warm and humid environmental conditions (Hennig et al., 1983; Andrews et al., 1993, 1994). Plant photosynthesis is a linked organic factor in the formation of tufa, as it uses $\mathrm{CO}_{2}$ for carbohydrate production (Golubić, 1969; Stumm and Morgan, 1981; Golubić et al., 1993); water chemistry, temperature, $\mathrm{pH}$, Eh, nutrients, and insolation are important controlling factors.

Cyanobacteria are commonly involved in stromatolite (boundstone) and oncolite formation (Riding, 2002). In addition there are also many taxa of sulphate-oxidizing and sulphate-reducing bacteria that play important roles in tufa formation. Fetid $\left(\mathrm{SH}_{2}\right.$-rich) gyttja or sapropel deposition can occur.

With regard to climate, recent tufas are found in nonarid and temperate climates (Pedley, 1990). Extremely arid climates do not maintain high water table levels, which are necessary for continuous tufa deposition. Likewise, cold Pleistocene periods will first be reflected in a sudden stoppage of the tufa growth, erosion, and karst development (dissolution). Due to base level lowering, a perched terrace will appear after the progression of the fluvial incision.

The tufa deposits in Priego were first studied from a geomorphological point by Virgili and Pérez González (1970); Madurga (1973) described the malacological content. A first attempt at dating based on amino acid racemization in gastropod shells was that of Torres et al. $(1994,1995,1999)$. The aim of this paper is the dating of the different tufa terrace levels using ostracode shell amino acid racemization and to interpret them as palaeoenvironmental proxies.

\section{Geological setting}

This study is focused on the Pleistocene tufa deposits located near the village of Priego on the eastern boundary of the Depresión Intermedia Basin, a piggyback basin created during the Alpine Orogeny (Fig. 1). During the Pleistocene a relatively large fluvial tufa system of terraces was formed, related to a three-river system formed by the Guadiela, Escabas and Trabaque rivers (Fig. 1). The main river, the Guadiela, is a tributary of the Tagus River, which flows into the Atlantic Ocean at Lisbon (Portugal). The three rivers have most of their catchment basins in the Iberian Range.

There was a common paleogeographical scenario during the whole three-river history:

- The predominance of strongly karstified carbonate rocks forming the drainage areas of the three rivers produced rich-in-calcium bicarbonate waters fed from karstic springs linked to a densely and deeply karstified mountain range. As at present, run-off waters rapidly infiltrated through karren fields, sinkholes and dolines.

- The three rivers' headwaters abruptly reached the open and flat-built Depresión Intermedia Basin through deeply cut canyons.

- After the $\mathrm{HCO}_{3}^{2-}$ rich waters reached the Basin realm, slow, expanding flow resulted. Waters became shallower and warmer and colonies of aquatic plants and algae flourished. A fast degassing $\left(\mathrm{CO}_{2} \uparrow\right)$ started deposition of tufa and associated facies (fluvial s.s.). Downstream, where due to previous deposition dissolved calcium bicarbonate was not available, the

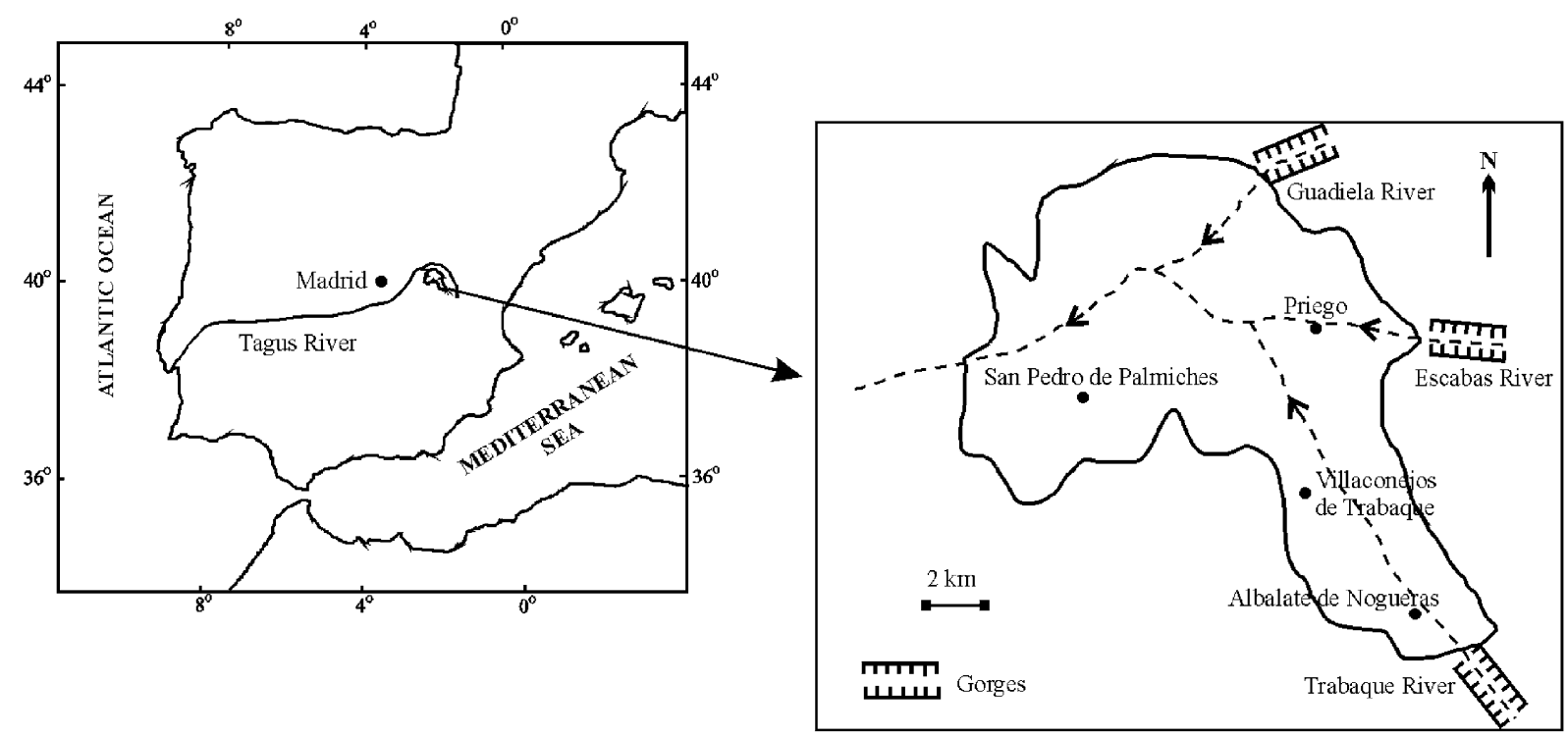

Fig. 1. Geographical location of the Priego area. Three rivers, Trabaque, Escabas and Guadiela, tributaries of the Tagus River, are shown with their catchment basins in the Iberian Range which produced tufa accumulations. 
tufa formation ceased and only clastic sediment accumulated on the alluvial plain. Similar situations were described by Violante et al. (1994) and Ford and Pedley (1996).

Height above the current thalweg level was used as a chronostratigraphical tool to make an initial estimate of the relative age of the tufa terraces in the Priego area, and to identify a set of six terraces (Figs. 2 and 3). If all the rivers worked exclusively as alluvial plain builders it is evident that the stratigraphical record of each section could represent just one palaeoenvironmental event, but intraclastic elements such as boulders of former phytoclastic and framestone beds, as well as intraclastic gravelly and sandy beds, record the destruction of former biogenic constructions. A barrier, even relatively short-lived, may be the origin of local and temporary base levels affecting the resulting height of further terraces, because downstream from the barrier, the fluviatile deposits cannot reach the same elevation as

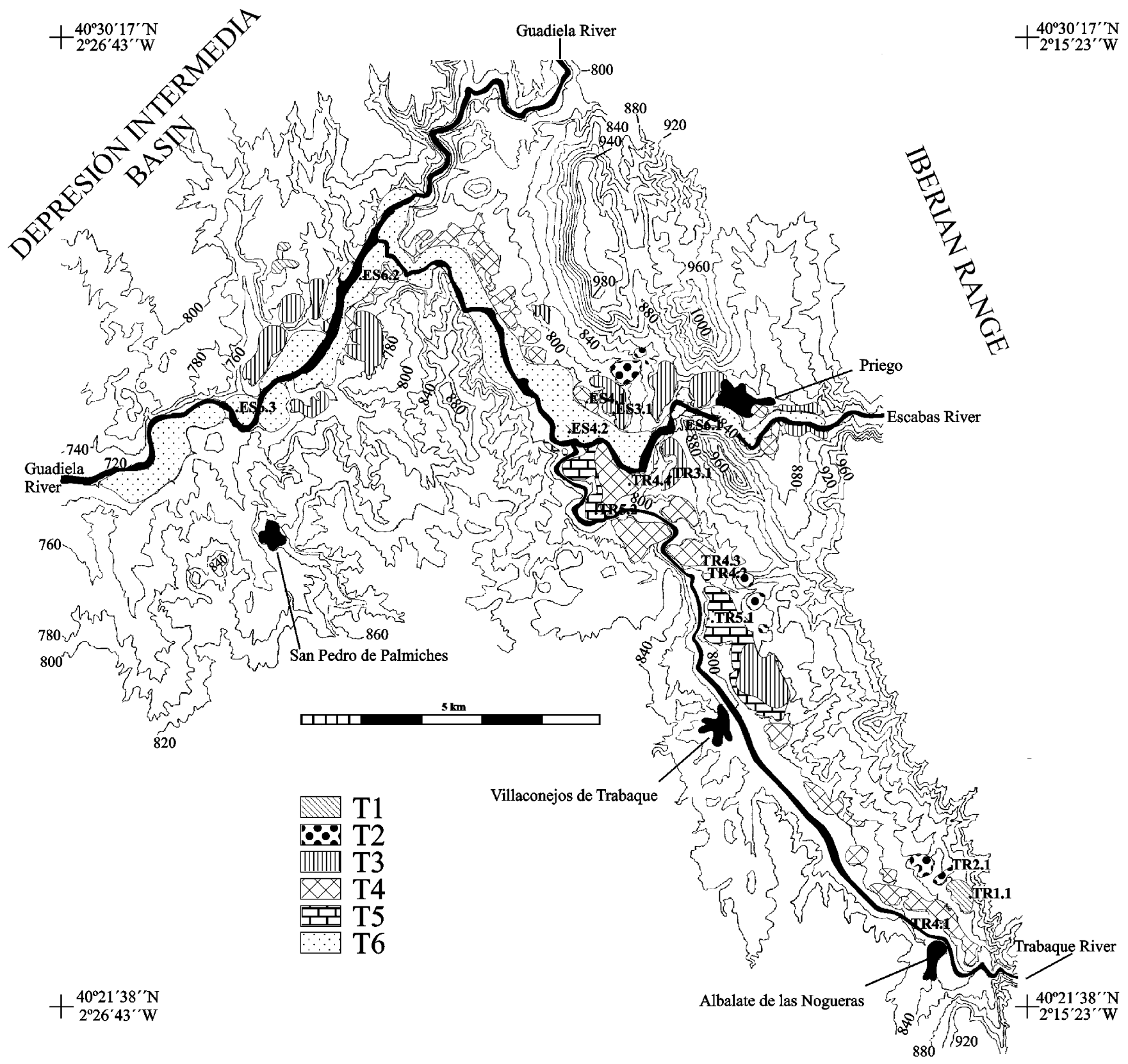

Fig. 2. Map showing the distribution of the tufa fluvial terraces in the Priego area according to their relative elevation above the current thalweg (T1-T6) and geographical location of the stratigraphic sections studied. Each section was designated according to its corresponding river (Trabaque river-TR; Escabas river-ES; Guadiela river-GU), the relative elevation above the current thalweg (T1-T6) and the downstream order along the river longitudinal profile. 

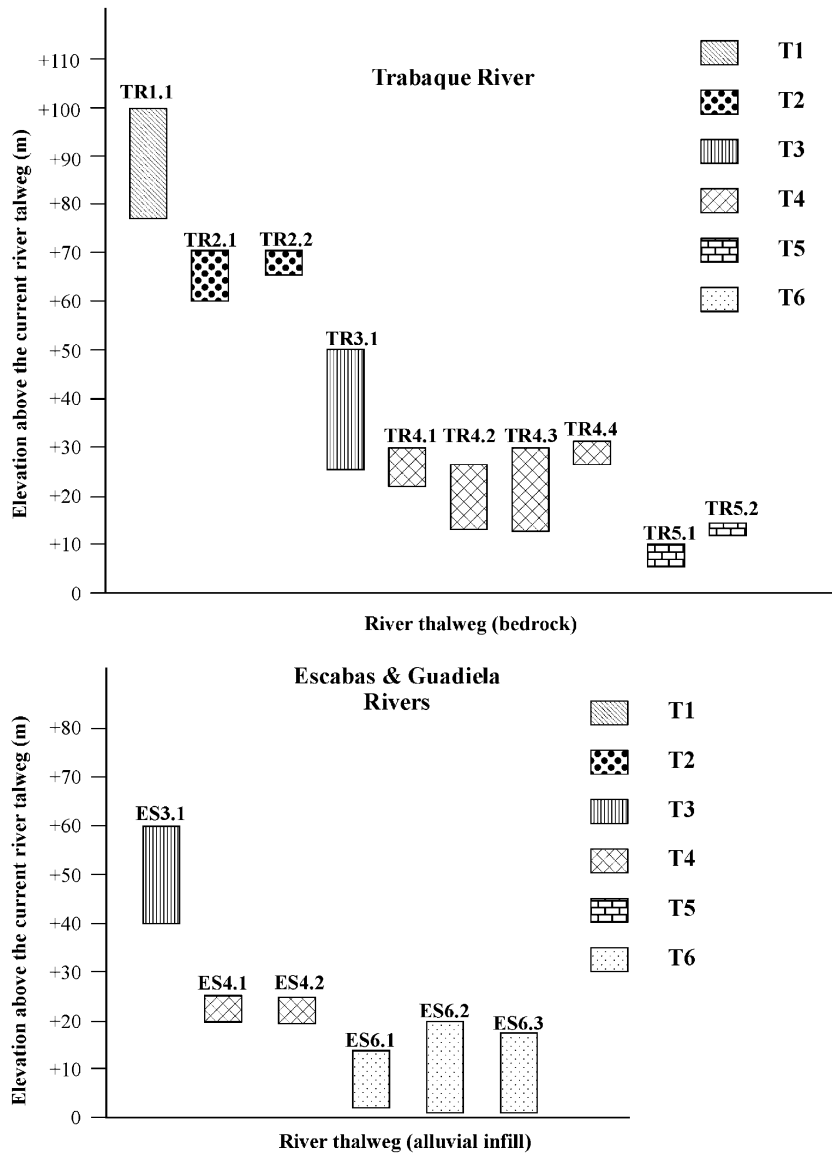

Fig. 3. Elevations of the stratigraphic sections above the current thalweg. In the Trabaque River the current thalweg consists of an alluvial plain of unknown thickness while in Escabas and Guadiela rivers it consists of bedrock. Each section was identified by the corresponding river and its geomorphological situation based on the elevation above the current thalweg. Each section was designated according to its associated river (Trabaque river-TR; Escabas riverES; Guadiela river-GU), the relative elevation above the current thalweg (T1-T6) and the downstream order along the river longitudinal profile. The horizontal axis shows the downstream order along the longitudinal profile. The vertical axis shows the elevation of each section above the current river thalweg.

those built upstream from the barrier. The age of the deposits beneath any floodplain is variable (Bull, 1991; Knox, 1996; Blum and Price, 1998; Blum and Törnqvist, 2000). Therefore, the relative age of the terrace surfaces was established for each of the rivers (Fig. 4). In the Trabaque River valley, six different terrace surfaces have been identified, while in the Escabas-Guadiela river valley, only five levels have been established. It is noticeable that the same terrace levels appear at different elevations in each graph. The relationship between terraces of the rivers was established from the TR3.1 section which, due to its geographical position, can be directly related to Trabaque and Escabas rivers.

\section{Sedimentological description of the tufa deposits}

Several classifications of tufa deposits have been proposed. We have decided not to use paleobotanical or physicochemical criteria as suggested by Pentecost and Lord (1988) and Geurts (1976). We prefer to employ a mixture of "paleo-geomorphological" (paleoenvironmental analysis) and sedimentological criteria, following Pedley (1990), Symoens et al. (1951), Buccino et al. (1978), Ordoñez and García del Cura (1983), Chafetz and Folk (1984), and Evans (1999).

The Priego tufa deposits can be put into the framework of Pedley's (1990) fluviatile model (braided and barrage): fully developed rivers, mostly braided, occasionally meandering, where extraclast input may be temporarily dominant, and with bars made of intraclasts, extraclasts and bioherms (phytoherms).

For facies description we have selected 14 sections (see Table 1 and Fig. 2 for locations) in order to obtain a more accurate image of the riverine systems. In Fig. 4 we present some representative sections of each of the six terrace levels. Each section was named according to the river it corresponded to (Trabaque river-TR; Escabas river-ES; Guadiela river-GU), relative elevation order (T1-T6), and downstream situation (Fig. 2). For example, TR4.2 refers to the second (2) downstream analysed section of the 4th terrace level (T4) from the Trabaque River.

\section{Methodology}

\subsection{Sampling}

Samples were taken in beds made up of marls or silt, which usually appeared to be protected from the sun by shelters made of structureless tufa, In any case, hole $1 \mathrm{~m}$ deep was dug before a $2 \mathrm{~kg}$ sample was taken. In the laboratory the sample was washed and sieved. After drying the sediment remnant $(>0.062 \mathrm{~mm}$ ) was analysed under a binocular microscope and ostracode shells were picked with the aid of a needle.

For amino acid racemization analysis at least 1500 ostracode single valves were necessary. We preferred to work with ostracodes because they are made of calcite, a more stable mineral than aragonite. Moreover, these shells are amino acid-rich: it is necessary to use some hundreds for a single sample, minimizing the sample error (standard deviation of the $D / L$ ratio, factors 3 and 5 of Murray-Wallace (1995)). It would be better to analyze the shells individually but this is not possible with the amino acid protocol and technique that we use (gas-chromatography). Since we cannot do that, and we have to analyze a significant number of valves within a sample, the few odd results of some shells are disguised. Several ostracode species were observed in the sampled 

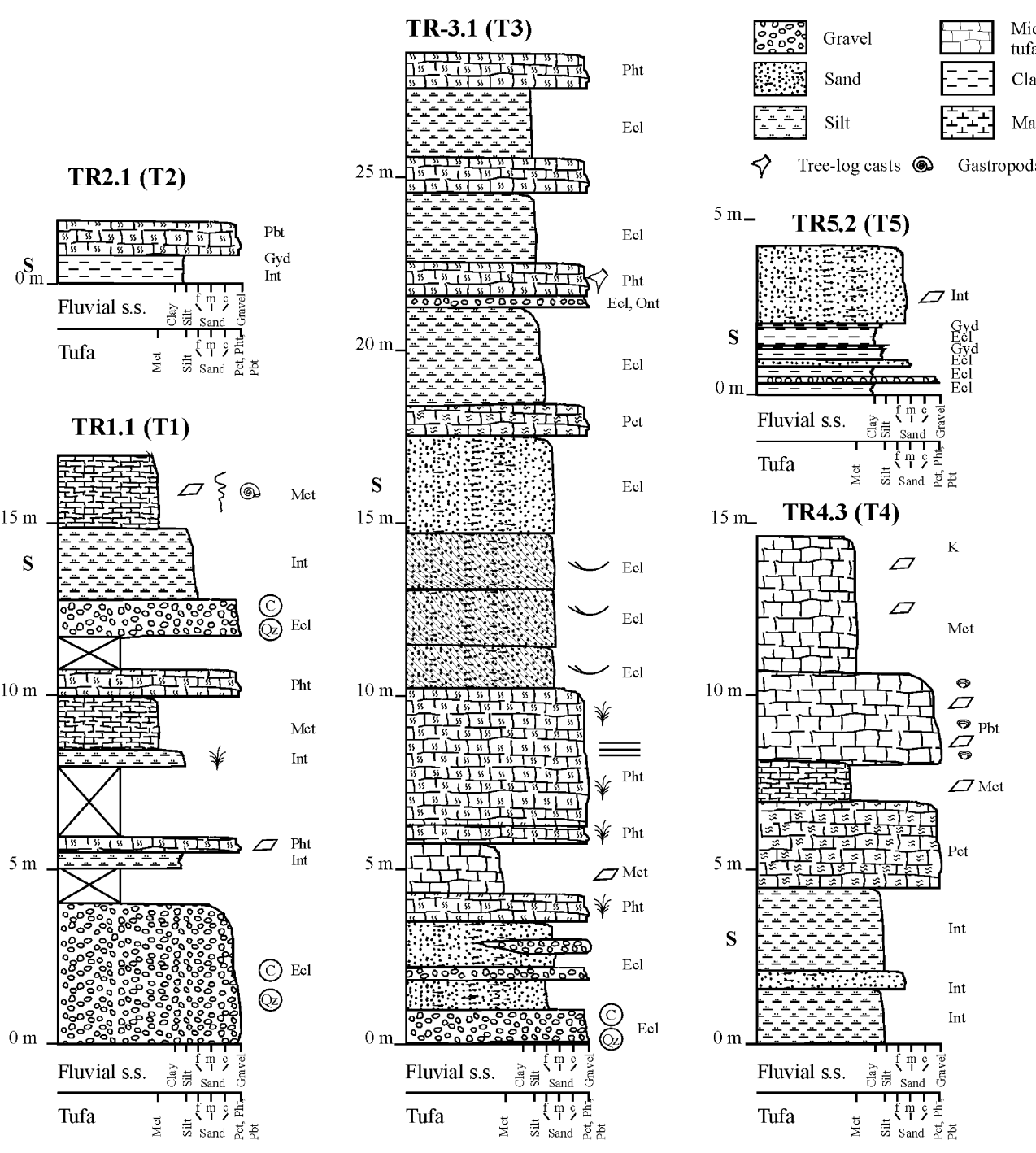

Fig. 4. Some representative stratigraphic sections of the Priego area with the identified facies. The samples location (S) is shown in each stratigraphic section. Tufa facies (Pedley, 1990) are also represented; Autochthonous deposits: Phytoherm framestone tufa (Pht), Phytoherm boundstone tufa (Pbt); Clastic deposits: Phytoclastic tufa (Pct), Oncolithic tufa (Ont), Intraclastic tufa (Int), Micritic tufa (Mct); Other deposits: Karst deposits (K), Extraclastic deposits (Ecl), Gyttja and Sapropel deposits (Gyd).

Table 1

Geographical locations

\begin{tabular}{llll}
\hline Localities & Latitude & Longitude & Elevation (m a.s.l.) \\
\hline TR1.1 & $40^{\circ} 22^{\prime} 30^{\prime \prime}$ & $2^{\circ} 16^{\prime} 19^{\prime \prime}$ & 920 \\
TR2.1 & $40^{\circ} 22^{\prime} 52^{\prime \prime}$ & $2^{\circ} 16^{\prime} 36^{\prime \prime}$ & 890 \\
TR3.1 & $40^{\circ} 26^{\prime} 11^{\prime \prime}$ & $2^{\circ} 19^{\prime} 41^{\prime \prime}$ & 840 \\
TR4.1 & $40^{\circ} 22^{\prime} 23^{\prime \prime}$ & $2^{\circ} 16^{\prime} 32^{\prime \prime}$ & 850 \\
TR4.2 & $40^{\circ} 25^{\prime} 42^{\prime \prime}$ & $2^{\circ} 19^{\prime} 07^{\prime \prime}$ & 815 \\
TR4.3 & $40^{\circ} 25^{\prime} 32^{\prime \prime}$ & $2^{\circ} 19^{\prime} 28^{\prime \prime}$ & 820 \\
TR4.4 & $40^{\circ} 26^{\prime} 18^{\prime \prime}$ & $2^{\circ} 20^{\prime} 06^{\prime \prime}$ & 800 \\
TR5.1 & $40^{\circ} 25^{\prime} 26^{\prime \prime}$ & $2^{\circ} 19^{\prime} 16^{\prime \prime}$ & 800 \\
TR5.2 & $40^{\circ} 26^{\prime} 02^{\prime \prime}$ & $2^{\circ} 20^{\prime} 32^{\prime \prime}$ & 795 \\
ES3.1 & $40^{\circ} 27^{\prime} 10^{\prime \prime}$ & $2^{\circ} 20^{\prime} 31^{\prime \prime}$ & 830 \\
ES4.1 & $40^{\circ} 27^{\prime} 07^{\prime \prime}$ & $2^{\circ} 20^{\prime} 40^{\prime \prime}$ & 790 \\
ES4.2 & $40^{\circ} 26^{\prime} 41^{\prime \prime}$ & $2^{\circ} 20^{\prime} 48^{\prime \prime}$ & 785 \\
ES6.1 & $40^{\circ} 26^{\prime} 50^{\prime \prime}$ & $2^{\circ} 19^{\prime} 36^{\prime \prime}$ & 800 \\
ES6.2 & $40^{\circ} 27^{\prime} 40^{\prime \prime}$ & $2^{\circ} 23^{\prime} 21^{\prime \prime}$ & 720 \\
ES 6.3 & $40^{\circ} 26^{\prime} 49^{\prime \prime}$ & $2^{\circ} 24^{\prime} 33^{\prime \prime}$ & 725 \\
\hline
\end{tabular}

fluvial terraces, though in most cases only Herpetocypris reptans (Baird) valves were selected. At horizons where Herpetocypris reptans (Baird) individuals were not abundant, they were picked together with individuals of Candona neglecta Sars and Candona angulata Müller or Ilyocypris bradyi Sars.

Although monogeneric samples are necessary to reduce taxonomically controlled variability in $D / L$ ratios, these three different ostracode genera were employed together to establish the age of the Priego fluvial terraces. Previous studies (McCoy, 1988; Oviatt et al., 1999; Kaufman, 2000; Kaufman et al., 2001) show that only slight differences between $D / L$ ratios from different ostracode genera (Candona and Limnocythere) which belong to different phylogenetic ostracode groups have been reported, 0.024 in $D$-aIle/ $L$-Ile values (McCoy, 1988) and 0.022 (Kaufman, 2000) or 0.048 
(Kaufman et al., 2001) in $D / L$-aspartic acid values. The ostracodes analysed in this paper belong to the same family (Cyprididae) and, therefore, should have similar racemization kinetics since they belong to the same phylogenetic group.

\subsection{Amino acid racemization analysis}

For sample preparation glassware, Eppendorf plastic micro test tubes, plastic micropipette tips and Pasteur pipettes were used, new from the factory. All the water used in the analysis was Milli-Q quality from Millipore. Chemicals were Merck, HPLC or spectroscopy grade.

Subsequently, the samples were prepared according to the Goodfriend (1991) and Goodfriend and Meyer (1991) protocol. Hydrolysis was performed in $6 \mathrm{~N}$ hydrochloric acid in test tubes with Teflon lined screw caps closed under a nitrogen atmosphere, in a heating block at $100{ }^{\circ} \mathrm{C}$ for $20 \mathrm{~h}$. After $4 \mathrm{~min}$ in an Eppendorf centrifuge, the supernatant was transferred, frozen in liquid nitrogen, and vacuum dried in a plastic desiccator. Samples were re-dissolved with distilled water. In a further step water was evaporated under vacuum.

The first derivatization step of the amino acids was the esterification with thionyl chloride in isopropanol. The vials, under a nitrogen atmosphere, were left to react on the heating block at $100^{\circ} \mathrm{C}$ for $1 \mathrm{~h}$. The second derivatization step was $\mathrm{N}$-trifluoroacetylation with trifluoroacetic acid anhydride. The vials were tightly closed and heated at $100^{\circ} \mathrm{C}$ for exactly $5 \mathrm{~min}$ on the heating block. Then, the samples were dissolved in $n$ hexane and transferred to injection vials. $0.2 \mu 1$ was injected into a Hewlett-Packard 5890 gas chromatograph. Helium was used as the carrier gas, at a column head pressure of $5.8 \mathrm{psi}$, along with a Chirasil-Val fused silica column from Chrompack. The detector was an NPD set at $300{ }^{\circ} \mathrm{C}$. Integration of the peak areas was carried out using the HP PEAK96 integration program from Hewlett-Packard that runs on a PC computer. The sensitivity limits of the method could be fixed according to the method induced racemization $(0.00-0.05$ depending on the amino acid considered). As a laboratory routine $D / L$-valine, $D / L$-alanine, $D$-Allo-isoleucine/ $L$-isoleucine, $D / L$-proline, $D / L$-aspartic acid, $D / L$-phenylalanine and $D / L$-glutamic acid peaks were identified.

\section{Results and discussion}

From the 14 sampled sections, 7 included only $H$. reptans (Baird) ostracodes (TR3.1, TR4.1, TR4.2, TR4.3, TR5.1, ES6.1, ES6.2), 5 localities consisted of valves from $H$. reptans (Baird), Candona angulata Müller and Candona neglecta Sars (TR4.4, TR5.2, ES3.1, ES4.1, ES4.2), and 2 consisted of valves from both $H$. reptans (Baird) and Ilyocypris bradyi Sars (TR1.1, TR2.1). To control analytical error, three analytical sub-samples were obtained from each sample (Table 2). We used the $D / L$ ratios of aspartic acid and glutamic acid all together for dating purposes because:

- The $D / L$ ratios of aspartic acid and glutamic acid measured in 19 analytical ostracode samples show strong correlations with each other (Table 3 ) and are, therefore, directly related to the age of the sampled horizons. Isoleucine, leucine and phenylalanine do not behave similarly.

- The correlation coefficients between $D / L$ ratios of phenylalanine and those of the other amino acids are low, meaning that not only age but also other factors have influenced the phenylalanine racemization.

Table 2

Mean values and standard deviation of $D / L$ ratios of aspartic acid and glutamic acid obtained from ostracodes from the Priego area and age calculation of each level

\begin{tabular}{|c|c|c|c|c|c|c|}
\hline Locality & $n$ & $\begin{array}{l}D / L \text { Asp } \\
\text { Mean }\end{array}$ & Std & $\begin{array}{l}D / L \text { Glu } \\
\text { Mean }\end{array}$ & Std & Age (ka B.P.) \\
\hline TR1.1 & 3 & 0.559 & 0.001 & 0.348 & 0.001 & $407.566 \pm 12.543$ \\
\hline TR2.1 & 6 & 0.484 & 0.001 & 0.219 & 0.000 & $253.636 \pm 10.188$ \\
\hline TR3.1 & 6 & 0.491 & 0.010 & 0.238 & 0.000 & $273.765 \pm 9.530$ \\
\hline TR4.1 & 3 & 0.333 & 0.002 & 0.117 & 0.001 & $107.856 \pm 8.685$ \\
\hline TR4.2 & 3 & 0.365 & 0.001 & 0.128 & 0.001 & $138.483 \pm 8.661$ \\
\hline TR4.3 & 6 & 0.375 & 0.001 & 0.122 & 0.008 & $134.624 \pm 15.480$ \\
\hline TR4.4 & 9 & 0.482 & 0.014 & 0.228 & 0.001 & $260.784 \pm 14.423$ \\
\hline TR5.1 & 3 & 0.334 & 0.002 & 0.115 & 0.002 & $105.781 \pm 4.480$ \\
\hline TR5.2 & 3 & 0.426 & 0.001 & 0.159 & 0.001 & $172.156 \pm 6.137$ \\
\hline ES3.1 & 3 & 0.403 & 0.001 & 0.136 & 0.001 & $189.890 \pm 23.971$ \\
\hline ES4.1 & 3 & 0.327 & 0.001 & 0.111 & 0.002 & $98.654 \pm 2.804$ \\
\hline ES4.2 & 3 & 0.332 & 0.002 & 0.129 & 0.000 & $123.229 \pm 31.928$ \\
\hline ES6.1 & 3 & 0.189 & 0.001 & 0.049 & 0.001 & $11.249 \pm 6.364$ \\
\hline ES6.2 & 3 & 0.184 & 0.002 & 0.048 & 0.001 & $10.253 \pm 5.377$ \\
\hline
\end{tabular}

Asp: aspartic acid; Glu: glutamic acid, $n$ : number of sub-samples (each sample was divided into three analytical samples). 
Table 3

Correlation coefficients $(r)$ between $D / L$ ratios of various amino acids from ostracode samples collected in Priego area

\begin{tabular}{|c|c|c|c|c|c|}
\hline & $D$-aIle $/ L$-Ile & $D / L \mathrm{Leu}$ & $D / L$ Asp & $D / L$ Phe & $D / L$ Glu \\
\hline \multirow[t]{2}{*}{$D$-alle $/ L$-Ile } & - & 0.868 & 0.838 & 0.786 & 0.839 \\
\hline & & $p: 0.001$ & $p: 0.001$ & $p: 0.002$ & $p: 0.001$ \\
\hline \multirow[t]{2}{*}{$D / L$ Leu } & & - & 0.749 & 0.699 & 0.834 \\
\hline & & & $p: 0.001$ & $p: 0.004$ & $p: 0.000$ \\
\hline \multirow[t]{2}{*}{$D / L$ Asp } & & & - & 0.576 & 0.943 \\
\hline & & & & $p: 0.020$ & $p: 0.000$ \\
\hline \multirow[t]{2}{*}{$D / L$ Phe } & & & & - & 0.556 \\
\hline & & & & & $p: 0.020$ \\
\hline$D / L \mathrm{Glu}$ & & & & & - \\
\hline
\end{tabular}

From the 14 sampled localities, 7 included only H. reptans (Baird) ostracodes (TR3.1, TR4.1, TR4.2, TR4.3, TR5.1, ES6.1, ES6.2), 5 consisted of valves from $H$. reptans (Baird), Candona angulata Müller and Candona neglecta Sars ostracodes (TR4.4, TR5.2, ES3.1, ES4.1, ES4.2) and 2 consisted of valves from both $H$. reptans (Baird) and Ilyocypris bradyi Sars ostracodes (TR1.1, TR2.1).

$D$-aIle/ $L$-Ile: $D$-alloisoleucine/ $L$-isoleucine; Leu: leucine; Asp: aspartic acid; Phe: phenylalanine; Glu: glutamic acid. $p$ : significance level.

- In spite of the correlation coefficients between $D / L$ ratios of leucine and isoleucine and those of the other amino acids being relatively high, the age calculation algorithms for dating "young" samples with these amino acids could not be established. This is due to the low racemization rates of leucine, and the epimerization of isoleucine. Likewise, in some chromatograms $D$-leucine and $D$-isoleucine peaks were not identified.

\subsection{Aminostratigraphy}

Aminostratigraphy consists in "placing in a stratigraphical order" sets of geological, paleontological or archaeological localities according to the measured $D / L$ ratios from the same group of fossils (genera), which were preserved under similar environmental conditions, inorganic geochemistry and thermal histories. Accordingly, each aminozone defined in the Priego area constitutes an almost-isochronous alluvial plain building event.

Six groups (aminozones) were established with the aid of a cluster analysis (complete linkage and Euclidean distance) from the aspartic acid and glutamic acid $D / L$ ratios obtained in ostracodes (Fig. 5). They were named AM1-AM7. Pretending a more general use of this aminozones we have omitted to use AM6 in the Priego area because we know (unpublished data; López Vera and Martínez Goytre, 1988, 1989) that along the 3rd oxygen isotope stages (OIS) tufas and speleothems accumulated in nearby areas. The six aminozones were further used for group identification (Figs. 6A and B). The mean $D / L$ ratios of each aminozone and the sections included in each one are shown in Table 4. In brief:

- A single terrace section (TR1.1) the highest one, appears in Aminozone 1.

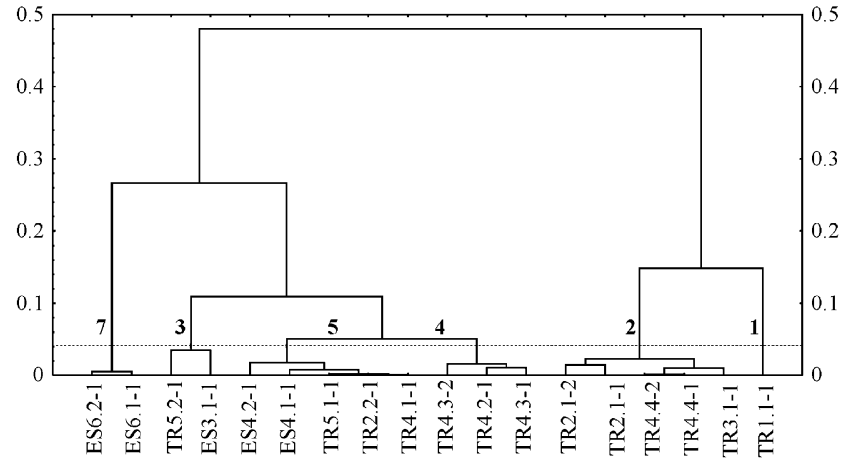

Fig. 5. Dendrogram (complete linkage and Euclidean distance) of the $D / L$ Asp and $D / L$ Glu values obtained from ostracodes from the Priego area. Each cluster was identified as an aminozone (A1oldest-A7 -youngest)

- Three terrace sections (TR2.1, TR3.1 and TR4.4) cluster at Aminozone 2.

- Aminozone 3 includes two terrace sections (TR5.2 and ES3.1).

- Aminozone 4 groups two sections (TR4.2 and TR4.3).

- Aminozone 5 includes four sections (ES4.1, ES4.2, TR4.1 and TR5.2).

- Two sections (ES6.1 and ES6.2) are included in Aminozone 7.

Based on the $D / L$ Asp values (Fig. 6A), the six aminozones are clearly distinguishable. However, according to their $D / L$ Glu values (Fig. 6B), sections belonging to the oldest (Aminozones 1 and 2) and the youngest (Aminozone 6) aminozones fit perfectly with the groups distinguished in the $D / L$ Asp diagram (Fig. 6A), whereas almost all intermediate aged sections are not clearly differentiated.

In general, there is good correspondence between the fluvial terrace levels, based on their relative elevation above their current river thalweg, and the aminozones. The highest terrace level (TR1.1), presumably the oldest 
one, fits very well with the oldest aminozone (AM1). In the second aminozone (AM2) three terrace sections are categorized (TR2.1, TR3.1 and TR4.4). The first one was near the Trabaque River canyon mouth, where the tufa deposition started. TR3.1 is $8 \mathrm{~km}$ downstream, in
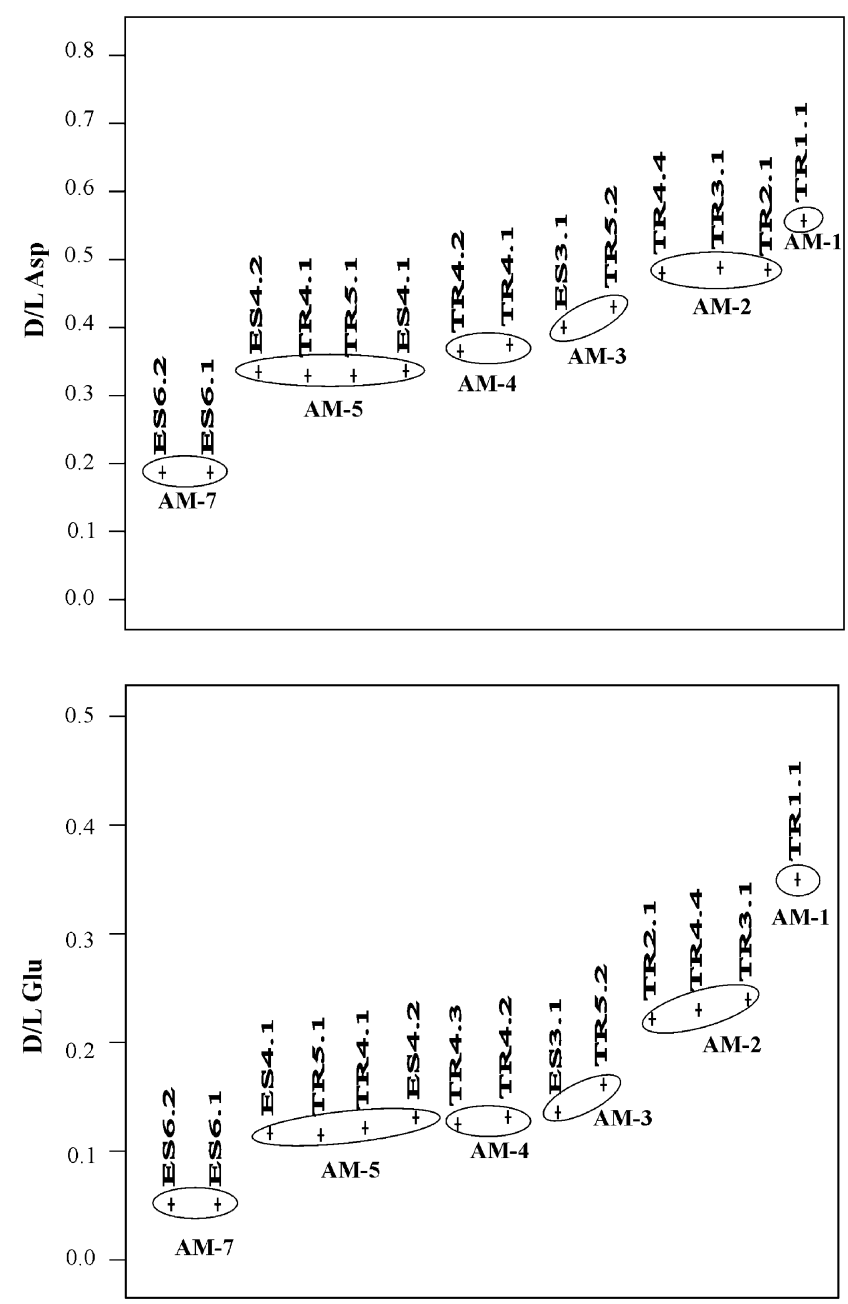

Fig. 6. Aminostratigraphy of the different stratigraphic sections of the Priego area based on the mean $D / L$ Asp (A) and $D / L$ Glu (B) values obtained from ostracodes. It is noteworthy that $D / L$ Asp values allow a better differentiation between intermediate age sections. After the aminostratigraphic analysis, the relative dating that was initially established for some terraces by geomorphological study was changed. an area of recent alluvial plain building where the real (higher) elevation above the river thalweg is masked. This aminozone also includes section TR4.4 which, according to its elevation, was placed at the 4th geomorphological terrace level. This is congruent with a downstream negative gradient elevation, which was observed in other sets of alluvial deposits.

In Aminozone 3 (AM3) two terrace sections are included (TR5.2 and ES3.1) according to their amino acid racemization ratios, although the sections appear at remarkably different elevations above the current river thalwegs. This can be explained by the different downstream behaviour of the Trabaque River, which slowed down incision after this alluvial plain was built. A misinterpretation of this outcrop (TR5.2) cannot be discounted. In the field, this area appears as a clearly three-stepped tufa terrace system which was interpreted as three independent tufa terraces. Due to the lack of good exposures, we cannot totally rule out the possibility that the stepping could be due to erosive processes affecting a single tufa terrace level. In this case, this section would correspond to a higher and older terrace level which was sampled near its stratigraphical bottom.

Two sections of the Trabaque River (TR4.2 and TR4.3) of the same geomorphological unit (T4) define Aminozone 4 (AM4). Two Escabas River terraces of the same elevation are categorized consistently in Aminozone 5. Two different terraces of the Trabaque river (TR5.1 and TR4.1) are included in this aminozone. As happens with the second aminozone, the upstream higher terraces fit with the lower downstream terraces, reflecting changes in the river gradient. The two lowermost terraces (ES6.1 and ES.2) fit very well with the most recent aminozone.

\subsection{Aminochronology}

The numerical age of each terrace has been calculated using the aspartic acid and glutamic acid $D / L$ ratios (aminochronology). The age calculation algorithms employed are those established by Ortiz et al. (in press) for ostracodes in the central and southern part of the

Table 4

Mean values and standard deviation of aspartic acid and glutamic acid $D / L$ ratios that characterize the ostracode aminozones established in Priego area and average age of the different Aminozones

\begin{tabular}{lllll}
\hline Aminozone & Localities & $D / L$ Asp & $D / L$ Glu & Age (ka B.P.) \\
\hline 1 & TR1.1 & $0.559 \pm 0.000$ & $0.348 \pm 0.000$ & $407 \pm 12$ \\
2 & TR2.1, TR3.1, TR4.4 & $0.479 \pm 0.024$ & $0.218 \pm 0.029$ & $263 \pm 14$ \\
3 & ES3.1, TR5.2 & $0.414 \pm 0.016$ & $0.147 \pm 0.016$ & $181 \pm 17$ \\
4 & TR4.2, TR4.3 & $0.371 \pm 0.006$ & $0.124 \pm 0.007$ & $136 \pm 13$ \\
5 & TR2.1, TR5.2, ES4.1, ES4.2 & $0.332 \pm 0.003$ & $0.118 \pm 0.006$ & $108 \pm 14$ \\
7 & ES6.1, ES6.2 & $0.186 \pm 0.003$ & $0.048 \pm 0.000$ & $11 \pm 4$ \\
\hline
\end{tabular}


Iberian Peninsula from the Lower Pleistocene to the present. These age calculation algorithms were developed using samples from the Guadix-Baza Basin (Granada, South Spain), the Padul peat bog (Granada, South Spain) and Priego (Guadalajara, Central Spain). The use of these samples all together, coming as they do from the Mediterranean climatic zone of the Iberian Peninsula, is justified by the fact that a similar thermal history can be inferred for all these areas given their similar current mean annual temperature (CMAT): $12-14{ }^{\circ} \mathrm{C}$ (cf. Torres et al., 1994, 1999).

For aspartic acid:

$\sqrt{t}=-2.666+18.027 \operatorname{Ln}\left[\frac{1+D / L}{1-D / L}\right] ; r=0.991, p=0.000$.

For glutamic acid:

$t=-39.59+622.25 \operatorname{Ln}\left[\frac{1+D / L}{1-D / L}\right] ; r=0.988, p=0.000$.

However, for young samples, with $D / L \mathrm{Asp}<0.401$ and $D / L$ Glu $<0.140$, other algorithms are more accurate and provide a better approach ( $c f$. Ortiz et al., in press). In fact, they were established for samples containing only $H$. reptans (Baird):

For aspartic acid:

$\sqrt{t}=-3.586+19.745 \operatorname{Ln}\left[\frac{1+D / L}{1-D / L}\right] ; r=0.993, p=0.001$.

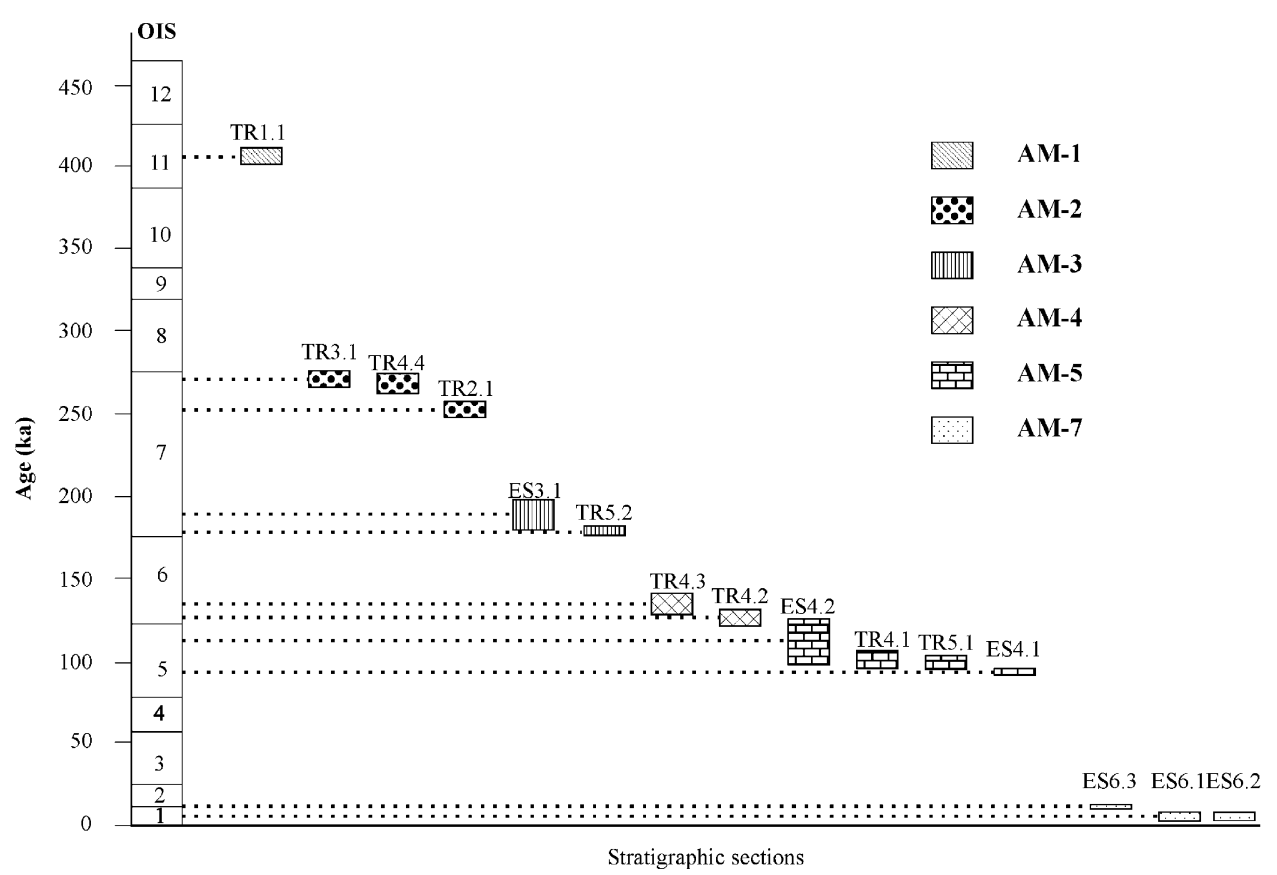

Fig. 7. Aminochronology of the Priego area stratigraphic sections after the numerical age calculation based on the $D / L$ Asp and $D / L$ Glu values. They are correlated with the marine OIS. The horizontal axis shows the stratigraphic sections.
Numerical dating was obtained by introducing the $D /$ $L$ ratios for the different localities into the algorithms of each amino acid. The age of a single terrace section is the average of the numerical dates obtained for each amino acid $D / L$ ratios measured in samples from that locality (Table 3). The age uncertainty of a section is the standard deviation of all the numerical dates calculated from the amino acid $D / L$ ratios measured in the samples

Previously, Torres et al. (1994) dated some fluvial terraces of this area by radiometric (U/Th) and palaeomagnetic methods (Table 5). The results obtained using the amino acid racemization method and $\mathrm{U} / \mathrm{Th}$ dating show a good correspondence. TR1.1, which is beyond the range of $\mathrm{U} / \mathrm{Th}$, was dated at $407 \pm 12 \mathrm{ka}$ using the amino acid racemization method and shows normal palaeomagnetic polarity. There is also a good correspondence between the ages of ES6.3 (U/Th) and of ES6.2 and ES6.1 (aard), which belong to the same terrace-level (T6).

The average age of each aminozone was calculated using the aspartic acid and glutamic acid $D / L$ ratios (Table 4). A relationship can be established between the aminozones and some paleoclimatological events defined in European and Spanish Pleistocene times. However, some considerations must be taken into of each locality Fig. 7. 
Table 5

$\mathrm{U} / \mathrm{Th}$ datings of different localities in Priego (Torres et al., 1994)

\begin{tabular}{ll}
\hline Locality & Age B.P. (ka) \\
\hline TR1.1 & $>350$ \\
TR4.1 & $105.132 \pm 7.648$ \\
TR4.3 & $156.005 \pm 7.970$ \\
ES6.3 & $18.196 \pm 1.382$ \\
\hline
\end{tabular}

account: Priego is located in the mediterranean climatic area where cold periods (Glacial) did not produce constantly frozen soils (permafrost) as in Northern Europe, but rather an increase of precipitation and moisture. On the other hand, during warm (interglacial and interestadial) episodes palaeoclimatic conditions result in increased dryness and temperature (cf. Ortiz, 2000; Torres et al., 2003b), with a similarity to current environmental conditions (Fig. 7).

Aminozone 1 ( $407 \pm 12 \mathrm{ka}$ B.P.) can be placed at the beginning of the 4th warm and arid period established by Ortiz (2000) and Torres et al. (2003a) for the southern part of the Iberian Peninsula, which corresponds to the Holstein Interglacial of the European glacial chronology. It can also be correlated with OIS 11 (Shackleton, 1995), and with the Dodoni Episode (warm) established in the Ioannina Basin (Greece) (Tzedakis, 1994).

Aminozone $2(263 \pm 14 \mathrm{ka}$ B.P.) correlates well with both OIS 7e and the Zitsa event of the Ioannina Basin (Greece) (Tzedakis, 1994). Aminozone 3 (181 $17 \mathrm{ka}$ B.P.) corresponds to OIS $7 \mathrm{a}$.

Aminozone $4(136 \pm 13 \mathrm{ka}$ B.P.) can be placed in a periods from the end of OIS 6 to the beginning of OIS 5 . Aminozone $5(108 \pm 14 \mathrm{ka}$ B.P.) can be correlated with the climatic ameliorations of the Eemian Interglacial (OIS 5). Finally, there is a good correspondence between Aminozone $7(11 \pm 4 \mathrm{ka}$ B.P. $)$ and the end of the Last Glacial Maximum and the beginning of the Holocene, OIS 1.

In brief, the tufa growth in the Escabas-Guadiela-Trabaque riverine system is related to warm periods (interglacials or interstadials). Tufa formation is enhanced by physico-chemical processes and biogenic precipitation, both influenced, among other factors, by temperature and precipitation. Tufa formation is severely limited when the temperature falls below $5{ }^{\circ} \mathrm{C}$ (Pentecost, 1995) and soil respiration increases with rising temperature, giving more $\mathrm{CO}_{2}$ and permitting greater limestone dissolution (Brook et al., 1983; Hennig et al., 1983). Higher temperatures also lead to greater degassing of $\mathrm{CO}_{2}$ in emerging groundwaters or when waters reach the canyon river mouths, along with increased aquatic plant photosynthesis and evaporation, all of which enhance tufa deposition. In the same way, adequate rainfall is necessary to maintain vegetation and soil. Increasing aridity leads to an absence of tufa growth.

According to Pentecost (1995), the majority of tufas appear within zones characterised by mean annual temperatures of $5-15^{\circ} \mathrm{C}$, and rainfall exceeding about $500 \mathrm{~mm} / \mathrm{a}$. For the Priego area, the current mean annual temperature is $12.9^{\circ} \mathrm{C}$ and the mean rainfall $525 \mathrm{~mm} / \mathrm{a}$ (Worldwide Bioclimatic Classification System index), which should be similar to the climatic conditions of the warm episodes (interglacials or interstadials). Furthermore, the palaeobotanical (leaf imprints) record from some tufa levels (TR.3.1) in the Priego area (Virgili and Pérez González, 1970) reveal the existence of tree species, most of them present in the area today, indicating a temperate climate. The interpreted increase of dryness in the central part of the Iberian Peninsula believed to have taken place during the warm episodes seemingly did not hinder tufa deposition. During cold periods, river incision processes were dominant and produced the scarp cutting and, thus, the formation of the tufa terraces.

\section{Conclusions}

Geomorphological analysis reveals a system of six terrace levels. Due to the different characteristics of the Guadiela-Escabas and Trabaque rivers, age-equivalent terrace levels appear at different elevations above the current river thalwegs. The sedimentary features of the tufa systems reveal a mixture of conventional fluvial sediments (extraclastic-in-nature deposits), tufa riverine and, in a minor extent, barrage deposits. Calcified upper plant stems or algae (Chara) talus acted as a source of intraclastic facies (silt to boulder-sized). In some cases, boundstone facies (large stromatolites) fixed extraclastic-in nature gravel bars.

Aminostratigraphy based on ostracode samples represents a formidable tool for stratigraphic purposes while gastropods gave more bizarre results (Torres et al., 1995). This can be interpreted as a result of the shell mineralogy: gastropod shells are mainly made of aragonite (Moore, 1969) which changes in time into more stable calcite, while the mineral component of ostracode shells is calcite (Sohn, 1958; Cadot and Kaesler, 1977). In general, there is good correspondence between the oldest (highest) and youngest (lowest) terrace levels and their aminozones, with less clear correspondence between intermediate levels. This lack of correspondence can be explained through the proposed model of the evolution of the river longitudinal profile morphology during an alluvial plain build-up event (Fig. 8): a "double-wedged" profile with its proximal apex at the knick point of the alluvial sedimentation near the canyon mouth, and the distal-apex located downstream, where a depletion of dissolved calcium 


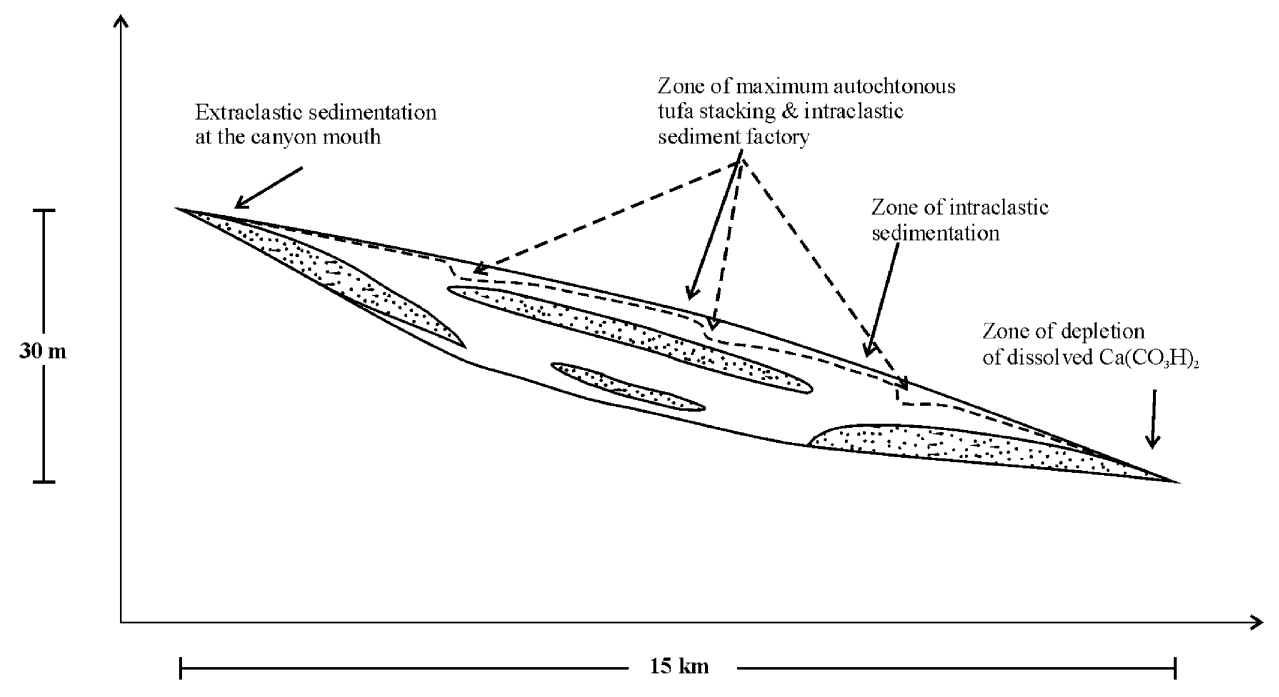

Riverine tufa deposits

Fig. 8. Outline of tufa accumulation process during a single event (aminozone) in the Priego area for riverine (solid line-Guadiela and Escabas rivers) and riverine-barrage (dash line-Trabaque river) models explaining the different elevations above the former thalweg attained at the top of adjacent sections. On a smaller scale a series of similar processes could appear downstream.

bicarbonate was produced. The maximum accumulation of tufa sediment was produced in the "central part" of the model. There, autochthonous tufa build-up (framestone and boundstone facies) was stacked, acting as a sediment trap (extraclastic and intraclastic in nature). This mechanism explains the appearance of coeval tufa terraces at different elevations.

In the Trabaque River (Fig. 8), the model seems to be more complex due to the barrage-linked abrupt changes in the river base level. Furthermore, sudden barrage destruction after their collapse would dramatically alter the height of newly formed terraces.

Age calculation algorithms (aminochronology) revealed that almost all the episodes of tufa deposition took place during odd OIS $(11,7 \mathrm{e}, 7 \mathrm{a}, 5$, and 1$)$, whereas one aminozone can be placed at the end of OIS 6. This means that the tufa accumulation processes were linked to palaeoclimatic events, i.e. warm periods (interglacials, interstadials, or odd OIS). Moisture probably was not a decisive factor due to the karst hydrological control of the area, as also happens with speleothem formation, which usually occurs during odd OIS (Durán et al., 1988; Baker et al., 1993).

\section{Acknowledgements}

Funding was obtained through the project "Paleoclimatological revision of climate evolution in Western Mediterranean region" (European Union, CE-FI2WCT91-0075). Prof. José Pedro Calvo from the Universidad Complutense de Madrid made helpful comments on an earlier draft. We are indebted to Dr. Veronika Meyer of the University of Bern who helped in the setting up of our laboratory. The Biomolecular Stratigraphy Laboratory has been partially funded by ENRESA.

\section{References}

Andrews, J.E., Riding, R., Dennis, P.F., 1993. Stable isotopic compositions of recent cyanobacterial carbonates from the British Isles: local and regional environmental controls. Sedimentology 40 , 303-314.

Andrews, J.E., Pedley, H.M., Dennis, P.F., 1994. Stable isotope record of palaeoclimatic change in a British Holocene tufa. Holocene 4, 349-355.

Arenas, C.G., Osácar, F., Sancho, C., 2000. Sedimentology and geochemistry of fluvio-lacustrine tufa deposits controlled by evaporite solution subsidence in the central Ebro Depression, NE Spain. Sedimentology 47 (4), 883-910.

Baker, A., Smart, P.L., Ford, D.C., 1993. Northwest European palaeoclimate as indicated by growth frequency variations of secondary calcite deposits. Palaeogeography, Palaeoclimatology, Palaeoecology 100, 291-301.

Blum, M.D., Price, D.M., 1998. Quaternary alluvial plain construction in response to glacio-eustatic and climatic controls, Texas Gulf Coastal Plain. In: Shankley, K.J., McCabe, P.J. (Eds.), Relative Role of Eustasy, Climate and Tectonism on Continental Rocks, vol. 59. SEPM Special Publication, Tulsa, pp. 31-48.

Blum, M.D., Törnqvist, T.E., 2000. Fluvial responses to climate and sea-level change: a review and look forward. Sedimentology 47 (1), $2-48$.

Brook, G.A., Folkoff, M.E., Box, E.A., 1983. A world model of soil carbon dioxide. Earth Surface Processes and Landforms 8, 79-86.

Buccino, D., D'Argenio, B., Ferreri, V., Brancaccio, L., Ferreri, M., Panini, C., Stancione, D., 1978. Il travertine della bassa valle del Tanagro (Campania). Studio della Geomorfologia, sedimentologia 
e geochimico. Bolletino della Società Geologica Italiana 97 , 617-646.

Bull, W.B., 1991. Geomorphic Responses to Climatic Change. Oxford University Press, New York, pp. 352.

Cadot, H.M., Kaesler, R.L., 1977. Magnesium content of calcite in caparaces of benthic marine Ostracoda. University of Kansas, Lawrence. The University of Kansas Paleontological Contributions $87,1-23$.

Chafetz, H.S., Folk, R.L., 1984. Travertines: depositional morphology and bacterially constructed constituents. Journal of Sedimentology and Petrology 54, 289-316.

Durán, J.J., Grün, R., Soria, J.M., 1988. Aportación del estudio geocronológico de espeleotemas y travertinos al conocimiento paleoclimático del cuaternario en la Península y Baleares. Congreso Geológico de España I 383-385.

Emeis, K.C., Richnow, H.H., Kempe, S., 1987. Travertine formation in Plitvice National Park, Yugoslavia: chemical versus biological control. Sedimentology 34, 595-609.

Evans, J.E., 1999. Recognition and implications of Eocene tufas and travertines in the Chadron Formation, White River Group, Badlands of South Dakota. Sedimentology 46 (5), 771-790.

Ford, T.D., Pedley, H.M., 1996. A review of tufa and travertine deposits of the world. Earth Science Reviews 41, 117-175.

Geurts, M.A., 1976. Formation de travertins postglaciaires in Belgique. In: Vogt, T. (Ed.), Colloque sur Tipes de Croûtres et leur repartition regionale. University Louis Pasteur, Strasbourg, pp. 76-79.

Golubić, S., 1969. Cyclic and non-cyclic mechanisms in the formation of travertine. Verhandlungen Internationale Vereinigung für Theoretische und Angewandte Limnologie 17, 956-961.

Golubić, S., Violante, C., Ferreri, V., D’Argenio, B., 1993. Algal control and early diagenesis in quaternary travertine formation (Rochetta a Volturno central Apennines). In: Barratolo, F. (Ed.), Studies on Fossil Benthic Algae. Special Paper Bolletino della Società Palaeontologica Italiana, vol. 1. Muchi, Modena, pp. 231-247.

Goodfriend, G.A., 1991. Patterns of racemization and epimerization of amino acids in land snail shells over the course of the Holocene. Geochimica et Cosmochimica Acta 55, 293-302.

Goodfriend, G.A., Meyer, V., 1991. A comparative study of the kinetics of amino acid racemization/epimerization in fossil and modern mollusc shells. Geochimica et Cosmochimica Acta 55, 3355-3367.

Hennig, G.J., Grün, R., Brunnacker, K., 1983. Speleothems, travertines and paleoclimates. Quaternary Research 20, 1-29.

Jacobson, R.L., Usdowski, E., 1975. Geochemical controls in a calcite precipitating spring. Contributions to Mineralogy and Petrology $51,65-74$.

Julià, R., 1980. La conca lacustre de Banyoles-Besalú. Centre d' Estudis Comarcals de Banyoles, Barcelona 167 pp.

Julià, R., 1983. Travertines. In: Scholle, P.A., Debout, D.G., Moore, C.H. (Eds.), Carbonate Depositional Environments. Memains American Association Petroleum Geologists 33, 64-72.

Kaufman, D.S., 2000. Amino acid racemization in ostracodes. In: Goodfriend, G.A., Collins, M.J., Fogel, M.L., Macko, S.A., Wehmiller, J.F. (Eds.), Perspectives in Amino Acids and Protein Geochemistry. Oxford University Press, New York, pp. 145-160.

Kaufman, D.S., Forman, S.L., Bright, J., 2001. Age of the Cutler Dam (late Pleistocene) Alloformation, Bonneville Basin. Quaternary Research 56, 322-334.

Kempe, S., Emeis, K.C., 1985. Carbonate chemistry and the formation of the Plitvice lakes. In: Degens E., Kempt, S.S., Herrera, R. (Eds.), Transport of Carbon and Minerals in Major World Rivers Part II. vol. 58. Mitteilungen des Geologisch-Paläontologischen Institutes der Universität Hamburg, pp. 351-383.
Knox, J.C., 1996. Fluvial systems since 20,000 years BP. In: Gregory, K.J., Starkel, L., Baker, V.R. (Eds.), Continental Palaeohydrology. Wiley, Chichester, pp. 87-108.

Leslie, A.B., Tucker, M.E., Spiro, B., 1992. A sedimentological and stable isotopic study of travertines and associated sediments within Upper Triassic lacustrine limestones, South Wales, UK. Sedimentology 39 (4), 613-630.

López Vera, F., Martínez Goytre, J., 1988. Edad radiogénica y estratigrafía isotópica de los edificios travertínicos del Puente de San Pedro (Guadalajara). Congreso Geológico de España II, 85-86.

López Vera, F., Martínez Goytre, J., 1989. Formación travertínica de Puente San Pedro (Guadalajara). Edad, ambiente de formación y evolución. Boletín Geológico y Minero 100 (2), 248-258.

Madurga, M.C., 1973. Los gasterópodos dulceacuícolas y terrestres del Cuaternario español. Boletín de la Real Sociedad Española de Historia Natural (sección Geológica) 71 (1-2), 43-165.

McCoy, W.D., 1988. Amino acid racemization in fossil non-marine ostracod shells: a potential tool for the study of Quaternary stratigraphy, chronology and palaeotemperature. In: De Deckker, P., Colin, J.P., Peypouquet, J.P. (Eds.), Ostracoda in the Earth Sciences. Elsevier, Amsterdam, New York, pp. 201-218.

Moore, R.C. (Ed.), 1969. Treatise on invertebrate palaeontology Part I. Mollusca 1 (Principles, gastropods). Geological Society of America, University of Kansas Press, Lawrence, Kansas.

Murray-Wallace, C.V., 1995. Aminostratigraphy of Quaternary coastal sequences in Southern Australia-an overview. Quaternary International 26, 69-86.

Ordoñez, S., García del Cura, M.A., 1983. Recent and Tertiary fluvial carbonates in Central Spain. In: Collinson, J.D., Lewin, J. (Eds.), Ancient and Modern Fluvial Systems, vol. 6. International Association of Sedimentology, Special Publication, pp. 485-497.

Ortiz, J.E., 2000. Evolución paleoclimática durante el Pleistoceno de la mitad sur de la Península Ibérica mediante el estudio paleontológico y geoquímico de ostrácodos de la cuenca de Cúllar-Baza (Granada, España). Ph.D. Thesis, Polytechnical University of Madrid, Spain, 563 pp.

Ortiz, J.E., Torres, T., Julià, R., Delgado, A., Llamas, F.J., Soler, V., Delgado, J., Numerical dating algorithms of amino acid racemization ratios from continental ostracodes. Application to the GuadixBaza Basin (southern Spain). Quaternary Science Reviews 23, $717-730$.

Oviatt, C.G., Thompson, R.S., Kaufman, D.S., Bright, J., Forester, R.M., 1999. Reinterpretation of the Burmester Core, Bonneville Basin, Utah. Quaternary Research 52, 180-184.

Pedley, H.M., 1990. Classification and environmental models of cool freshwater tufas. Sedimentary Geology 68, 143-154.

Pentecost, A., 1992. Carbonate chemistry of surface waters in a temperate karst region: southern Yorkshire. Journal of Hydrology 139 (1-4), 211-232.

Pentecost, A., 1995. The Quaternary travertine deposits of Europe and Asia Minor. Quaternary Science Reviews 14, 1005-1028.

Pentecost, A., Lord, T., 1988. Postglacial tufas and travertines from the Craven district of Yorkshire. Cave Science 15 (1), 15-19.

Riding, R., 2002. Structure and composition of organic reefs and carbonate mud mounds: concepts and categories. Earth-Science Reviews 58 (1-2), 163-231.

Shackleton, N.J., 1995. New data on the evolution of Pliocene climatic variability. In: Vrba, E.S., Denton, G.H., Partidge, T.C., Burckle, L.H. (Eds.), Palaeoclimate and Evolution with Emphasis on Human Origins. Yale University Press, New Haven, CT, pp. 242-248.

Sohn, I.G., 1958. Chemical constituents of ostracodes: some applications to paleontology and paleoecology. Journal of Paleontology $32,730-736$. 
Stumm, W., Morgan, J.J., 1981. Aquatic Chemistry. An Introduction Emphasizing Chemical Equilibria in Natural Waters, second ed. Wiley, New York $780 \mathrm{pp}$

Symoens, J.J., Duvigneaud, P., Vannden Bergen, C., 1951. Aperçu sur la vegetation des tufs calcaires de la Belgique. Bulletin Societé Royale Botanique de Belge 83, 329-352.

Torres, T., Zapata, J.L., 1986. Evolución Cenozoica de la Depresión Intermedia (Cuenca-Guadalajara). Acta Geológica Hispánica 21-22, 437-442.

Torres, T., Canoira, L., Cobo, R., García, P., García Cortés, A., Juliá, R., Llamas, J., Hoyos, M., Meyer, V., 1994. Aminoestratigrafia y aminozonación de los travertinos fluviales de Priego (Cuenca, España Central). Geogaceta 17, 102-105.

Torres, T., Cobo, R., Canoira, L., García Cortés, A., Grün, R., Hoyos, M., Juliá, R., Llamas, J., Mansilla, H., Quintero, I., Soler, V., Valle, M., Coello, F.J., García-Alonso, P., Guerrero, P., Nestares, T., Rodríguez-Alto, N., Barettino, D., 1995. Reconstrucción paleoclimática desde el Pleistoceno medio a partir de análisis geocronológicos e isotópicos de travertinos españoles". Area B: Travertinos fluviales de Priego (Cuenca). Technical project (ENRESA), Madrid, $108 \mathrm{pp}$.

Torres, T., Llamas, J.F., Canoira, L., García-Alonso, P., Ortiz, J.E., 1999. La racemización/epimerización de aminoácidos como herramienta geocronológica y paleotermométrica. ENRESA, publicación técnica 9/99, Madrid, 147 pp.

Torres, T., Ortiz, J.E., Alcalde, C., Badal, E., Castroviejo, R., Cobo, R., Chacón, E., Delgado, A., Demoustier, A., Fernández-Gianotti,
J., Figueiral, I., García-Amorena, I., García-Martínez, M.J., Llamas, J.F., Julià, R., Postigo, J.M., Rubiales, J.M., Reyes, E., Sepherd, T., Soler, V., Valle, M., 2003a. Evolución paleoambiental de la mitad sur de la Península Ibérica. Aplicación a la evaluación del comportamiento de los repositorios de residuos radiactivos. ENRESA, publicación técnica 4/03, Madrid, $173 \mathrm{pp}$.

Torres, T., Ortiz, J.E., Soler, V., Reyes, E., Delgado, A., Valle, M., Cobo, R., Julià, R., Badal, E., García de la Morena, M.A., GarcíaMartínez, M.J., Fernández-Gianotti, J., Calvo, J.P., Cortés, A., 2003b. Pleistocene lacustrine basin of the east domain of GuadixBaza basin (Granada, Spain): sedimentology, chronostratigraphy and palaeoenvironment. In: Valero-Garcés, B. (Ed.), Limnogeología en España: un tributo a Kerry Kelts. Consejo Superior de Investigaciones Científicas, Madrid, pp. 151-185.

Tzedakis, P.C., 1994. Vegetation change through glacial-interglacial cycles: a long pollen sequence perspective. Philosophical Transactions of the Royal Society of London B 345, 403-432.

Violante, C., Ferreri, V., D’Argenio, B., Golubić, S., 1994. Quaternary travertines at Rochetta a Volturno (Isernia, Central Italy). Facies analysis and sedimentary model of an organogenic carbonate system. PreMeeting Fieldtrip Guidebook A1, International Association of Sedimentology Ischia'94, 15th regional meeting, Roma, Italy, pp. 3-23.

Virgili, C., Pérez González, A., 1970. Quelques travertins du rebord nord-est du bassin tertiaire du Tage. Bulletin de l'Association Géographes Francais 377-378, 53-55. 